\title{
MANIFESTATION OF STRESS IN ORGANISATIONS
}

\author{
Ada loana DOBRESCU ${ }^{1}$
}

\begin{abstract}
This article presents the theroretical framework and the results of research conducted in an organisation of airship and spaceship manufacturers with respect to the concept of stress. The main objective of the research is to underline the way in which employees of this company succeed in overcoming the tension present in the workplace.
\end{abstract}

Key words: stress, burnout syndrome, coping strategies, professional stress

\section{Introduction. Defining Concepts}

This article describes various ways in which stress manifests itself in organisations. Stress as a scientific concept was first mentioned by Selye, in the medical field. He would define stress, in the Nature magazine, in 1936, as a "general symptom of adaptation to various environment factors" (Selye, 1984, p.185-186).

Stress can manifest itself in various forms: physical, biological, or psychological; and as a common definition, it designates "the importance of harmful factors upon individuals that can lead to the disappearance of balance in the organism (homeostasis)". (lamandescu, 1993, p.15)

Golu considers that physical stress represents "a state of tension, straining and discomfort, determined by emotional agents with a negative significance, of frustration or repression of some states of motivation (needs, desires, aspirations), of difficulty or impossibility to solve some problems (apud lamandescu, 1993, p.11).

Stress has become a real social issue that can be found in all fields of activity, impacting strongly upon the entire organism. Nevertheless, people react differently to stress, considering emotional and motivational resources, temperamental charateristics, and the context in which a certain stressor event takes place (Zorletan et al., 1996).

According to specialists in the medical field, the body produces a hormone called cortisol when under stress. Depending on the quantity in which it is produced, it can have different reactions in the organism, the overworked brain produces a large quantity of cortisol, this reaction being a fight or flight response from the body

\footnotetext{
${ }^{1}$ Transilvania University of Braşov, ada.dobrescu@unitbv.ro
} 
(Emmet, 2009/2017).

Selye (1984) considers that there are three stages of stress:

1. The alarm reaction - the general action through which the body defends itself;

2. Resistance - as a person is exposed to stressful situations, they acquire resistance and possess certain means that help them adapt (Andreescu and Liţă coord., 2006); and

3. Exhaustion - a person cannot adapt to a stressful situation anylonger, it is impossible for them to defend themselves and therefore they are brought down (Andreescu and Liţă coord., 2006);

\section{Causes of Stress}

Stress has become an acute issue which is found in all fields of activity, having a strong impact on the organism. Most times, the effects of stress are negative, because they produce changes on the psychic state, on the immune system, and also carry a risk of illness.

There are a multitude of causes that can generate stress. There could be biological factors (illnesses), physical ones (burns, hits, unpredictable noises, natural disasters/calamities); physiological (hunger, thirst - unsatisfied needs) or psychological (important, happy or unhappy changes in a somebody's life: the birth of a child, wedding, baptism, the death of a dear person, divorce, unemployment, job restructuring in a company, job change, the failure of a member of the family in an important exam (general certificate of lower-secondary education, baccalaureate, physical abuse, sexual abuse, or financial abuse).

It seems that psychic stress with the same cause does not always present in the same way. It depends on the state of the person at that moment, the significance given to the respective event, and cognitive genetic traits that contribute to the solution discovered by an individual when a potential stressor occurs (Goupil apud. lamandescu, 1993).

\section{Types of Stress}

There are two types of stress depending on its polarity: positive stress or eustress which manifests as a form of stimulating/mobilising the organism and human psyche under performance circumstances (for instance, in the Olympic Games, the athletes found in competition with others succeed in breaking their own records and negative stress or distress (which has harmful/destructive implications on the human organism and psyche, the human being not being able to overcome that obstacle: for instance, anxiety states, illness, or compulsive eating) (Selye, 1974 apud Stoica, 2007).

There is another classification depending on how overworked the human body and psyche are: hyperstress is associated with suprastimulation, the individual cannot adapt and ends up in exhaustion and hypostress in which substimulation leading to a state of monotony takes place.

According to Andreescu and Liţă $(2006$, p.44) we have four types of stress: 
1. Basal stress - the type of stress encountered in all people, the persons desire something, what happens in their lives does not contribute to what they want to achieve, which leads to reactions of fury and tension;

2. Cumulative stress - due to difficult happenings, with frequency, depth and a long period, if it is overlooked, it can lead to burnout (it characterises workaholic persons who need better time management, clear limits and a correct perception of risks);

3. Traumatic stress - caused by the consequences of an unexpected, violent event, which causes physical and/or emotional wounds (for instance, abuse, illness, death, or loss of dwelling); and

4. Post-traumatic stress - occurs if the symptoms of traumatic stress last more than a month (also called stress disorder).

If the first two types of stress can be managed by unspecialised persons, for the last two a specialist in the field (a psychologist or psychotherapist) must be sought.

There is a correlation between the concept of stress and that of personality. Given that each person is born into a certain family, lives in a certain environment, has certain life experiences, and is surrounded by certain persons, they form principles and defence mechanisms depending on their reasons and on what they have observed until then. For this reason, researchers have noted that in order to prevent stress, it is very important to know one's own personality (Stora, 1999).

For this reason, introverts turn their attention more towards themselves, are vulnerable to failure, and become panicked at competitive moments. On the other hand, extroverts tend towards precise, real things; are energetical, enthusiastic and communicate better with others.

Regarding rigidity, those who possess this trait are stubborn, not open to new experiences, and do not trust their own strength so they experience stress more often. On the other hand, those who are flexible adapt more easily and experience less stress (Floru, 1974).

\section{Coping Strategies}

Coping strategies are the methods of countering stress or "a series of cognitive and behaviour efforts for managing the specifically internal and/or external demands, assessed as exhausting the resources of a person" (Lazarus, Folkman, 1984 apud. Preda, 2010, p.8).

Lazarus and collaborators (1984, 1987 apud. Andreescu and Liţă, coord., 2006, p.212, 213) distinguish between two categories when classifying coping strategies: $a$. Coping centred on the issue - the issue is represented by a stressful situation, and individuals structure, their ideas to reach their objective, to solve the problem, also applying methods used in similar situations which helped them attain the desired result; and

b. Coping centred on the emotion - the individuals act against a situation in a passive manner, not removing the negative effects for good, but reducing them, excluding the idea of facing the situation. 
Among the most commonly used coping methods are: the attempt to live as healthily as possible, solving difficulties directly, avoiding conflicts, relaxation after work by means of various activities, allotting time for particular aspects, accepting weaknesses of our own person and sharing pressures with those around (Kyriacou, 2001 apud. Neç̧oi, 2011, p.54).

\section{Burnout Syndrome}

In literature, the term burnout syndrome implying exhaustion is used. The more often the syndrome is present and the longer is lasts, and more severe the effects on the human body are. Most times, people facing stress reach a level of exhaustion because they do not give special importance to this aspect; the list of priorities being different, they do not perceive the level of severity, which causes various suffering. Stress shouldn't be regarded as a disease, but as a state that can intensify and will certainly lead to disease (Selye, 1962, apud. Zlate, 2007).

This syndrome is also found under the name of "syndrome of chronic exhaustion" and is encountered especially in persons who are always worried; this way, one who is always calm and does not get agitated by everything that happens around them, including for those surrounding them, has fewer chances of getting exhaustion, as compared to a person who is preoccupied with all sorts of worries (Emmett, 2009/2017, p.36).

In recent years, burnout syndrome has been a common topic for those in the area of organisational psychology, implying overwork in the workplace.

Among the promoters of the term, Freudenberger considers burnout as "a state of chronic fatigue, depression, and frustration, generated by the devotion to a cause, a lifestyle or a relationship that fails to produce the expected rewards and finally leads to diminishing work involvement and fulfilment" (Freudenberger, Richelson, 1980 apud. Zlate, 2007, p.598).

As the burnout or "the disease of the fighter" definition says, it occurs in persons who get involved too much.

Fengler $(2013 / 2016$, p.53, 54, 98) proposes a list with principles through which burnout can be prevented. These are: the moderation of objectives, objectives in accordance with one's own possibilities, capacity of realisation through one's own forces, minibreaks, and ceasing pressure.

\section{Professional Stress}

Both personal and professional life exposes us to some trials, sometimes good, sometimes bad, to which we react depending on the defence models that first come to our mind. It depends on the way we look at things. Depending on each one's personality, for instance, a new job can be regarded as a good thing, a new start in another organisation, another culture and new colleagues, but a new job can also be regarded through the difficulties regarding the integration and new assignments. As in the case of termination of employment, the event can be regarded as the end of the road or a new beginning. 
According to Turcotte (1988 apud. Stoica, 2007, p.24-25), professional stress occurs firstly when here is no blend between the physical and psychic capacity of an individual and the necessities of carrying out tasks in the workplace, and secondly, when there is no blend of the necessities of an individual that can be fulfilled in the workplace by means of a specific atmosphere.

According to Batâr (coord.)(2001,p.23), a person who enters an organisation has to comply with rules and necessities typical of that organisation and the position held, and the work situations considered "stressful" are generated by the activities in which danger is present, a high or low level of stress often occur. When the frequency of such situations is high, a lack of balance is created, which leads to the occurrence of stressful situations.

Therefore, says Batâr (2001), the reaction to stress is individual, each individual acts according to the assessment of a situation and to the sense they assign to that situation; the result depends only on the person in question, on the way they choose to manage that stressful context.

Pastor et al. (2005) mention a series of stressor factors in professional life: job loss, job change, a demand of pay rise, decision-making, work conflicts, and factors pertaining to the physical atmosphere in the workplace: loud noises or inadequate light; or social: an authoritative boss.

Simion (2015) also mentions other factors that can generate stress in the workplace: the pressure of deadlines in a certain project, numerous tasks in a short period of time, the lack of necessary training for a certain position, aspiration to higher positions, deficiencies in designing job tasks and the pressure on employees in decision-making positions.

As reactions to stress there can be situations in which the employees give up on going to work or leave a position through early retirement (Canciu and Bardoc, 2011).

Necşoi (2011) considers that there can be cognitive reactions too, following stressful situations. These include negative views on life, memory disorders, inability to concentrate; emotional reactions: a high level of anxiety, panic, fear, or low selfesteem; behavioural reactions: alcohol consumption, aggressive behaviour, or neglecting relationships.

In terms of the effects of stress, Zorleţan et al. (1996) indentify: subjective effects boredom, irascibility; behavioural effects - the possibility of causing a work accident, violent behaviour; cognitive effects - reducing the possibilities when having to make a correct decision; physiological effects - a change in the heartbeat; organisational effects - a decrease in efficiency and the motivation of employees.

There is also the concept of management of professional stress, which implies identifying strategies for reducing stress. It is a continuous process that implies the monitoring of stressor factors, of symptomatology generated by a constant action of risk factors and applying the most efficient methodology to assist the affected subjects (Simion, 2015).

According to Bărăian et al.(2010), communication plays a major role in stress management. In an organisation, stress can be removed or diminished by means of good organisation, control over all activities, planning all actions in detail, 
consultation with other members. Eliminating stress of employees leads to the correct functioning of the organisation.

According to Bogathy (coord.)(2004) there is a series of secondary interventions such as individual or group therapies, feedback from specialists, relaxation methods and training.

Pastor et. al (2005) present strategies of preventing professional stress related to an organisation: varied tasks that maintain the interest of employees, from which they learn new things, the existence of some cooperative relationships between employees and their managers, facilitating the communication process between departments and levels of hierarchy of an organisation willing to develop their employees.

There are programmes for significant stress reduction through nutrition, physical exercises, recommendation of a daily water consumption level, exposure to sunlight and clean air, rest, and positive self-esteem (Stoica, 2007).

Organisational stress can also be diminished by the method of "workspace organisation": a pleasant environment, not cluttered with papers and futile things, with a photo of (a) loved one(s) and silence (Stoica, 2007).

As a conclusion of our documentation, we can state that it depends on the way in which people manage sources of stress so that they are not discouraging and so that they do not affect the quality of life and their state of health.

\section{Objectives and Methodology}

This article comprises research conducted in collaboration with the students at the seminars I teach, on the theme of stress. It is an explorative-descriptive type of research carried out with the help of a semi-structured interview with employees of Premium Aerotec S.R.L. This company, based in Ghimbav, Braşov is a spaceship and airship manufacturer. It collaborates with four headquarters in Germany. It is a developer of component parts and aeronautical structures for civilian planes and military transport aircraft: the company in Brasov produces and assembles metallic components for aircraft.

Semi-structured interviews were carried out until we reached methodological saturation, on employees aged between 23 and 52 . Subjects carry out their activity in different departments and hold positions such as: Production Trainer, Training Instructor, Production Planner, Production Engineer, fire safety and security technician, Environment Officer, and from the Human Resources Department - a Human Resources consultant, a Human Resources specialist and also employees dealing with quality.

The main aim of the reseach is to underline the way in which the employees of this company succeed in overcoming the tensions present in the workplace, that generate stress and in continuing their professional activity at a normal pace. Managing the stress caused by work-related aspects is done at an individual and organisational level. Through this research, I will try to describe the solutions proposed as alternatives to stress-related phenomena. 
The objectives of the research were as follows:

1. Underlining the implication of job responsibilities on stress in the workplace;

2. Identifying repercussions of private life that present different difficulties related to the professional field;

3. Detailing the main factors that cause stress among employees;

4. Underlining the response of employees to stressful situations; and

5. Describing ways in which the employees of the company fight stress in the workplace.

\section{Data Analysis and Interpretation}

In this stage, we used theoretical and open coding in order to analyse and interpret the information included in the interviews. I mention some of the categories identified: personality traits, responsibilities, aims for an efficient functioning of the factory to which the employees desire to contribute, the interference of professional and private life, elements considered important in the opinion of employees (satisfaction, energy, moments deprived of stress), stressful factors, reactions, solutions to calm down in a stressful moment, the consequences of stress, ways of diminishing stress, and measures taken with regard to fighting stress.

Regarding the causes of stress in the workplace, the main ones that are mentioned here: overwork, time pressure, unforeseen activities in the workplace.

There is a tight connection between professional and personal life, problems in one of them generate stress in the other. An effect of this association is represented by the impossibility of focusing on work tasks because of personal life issues. In order to avoid the transfer of stress from one area to the other, the best solution is detachment, at the moment when the employees leave the workplace, job-related problems should remain there and the other way round. Men resort to methods of cooling-down more often than women, the most frequent being leaving the room for a short period.

Some employees mention that recruitment could be a cause of stress, because working with people can sometimes be difficult. Also, authoritative bosses or the pressure of deadlines can be other causes of stress. As temporary solutions in countering stress, "going to the bathroom and washing one's face" or listening to music during work hours if possible are two potential solutions.

In this company, it seems that the job description of a woman is more demanding than that of a man. They deal with recruitment, health care packages, distributing health cards and payslips, coordinating and organising transports and checking work equipment. The factors that cause stress are: new tasks, overwork, and working with people.

Persons of male gender deal with the final verification of parts before delivery and solving quality issues, here stress comes from the necessity of quickly solving problems and the high number of demands.

The most important factor that causes stress in the workplace is time pressure, followed by overwork, coming from seniors or colleagues. There are also factors that 
pertain to unforeseen activities or new assignments that take one out of one's routine, but also the factors of relating with colleagues (for instance, the indifference of colleagues to observe certain procedures). The only times when stress is absent are lunch breaks or the moment before starting the work hours.

A solution to counteract stress is to have, for each employee, an element within the tasks performed that creates satisfaction, which determines one to work with pleasure and to lay less emphasis on negative elements.

The way of relating to a difficult task creates reactions that are negative most times, that come in a package with various outlets: smoking or consumption of soft drinks.

The consequences of stress can lead to a change in the state of well-being (for instance, insomnia or dreams relating to unfulfilled job tasks).

Employees have stated the importance of an organisational atmosphere in fighting stress through methods such as: a pleasant work atmosphere, comfortable space, communication with colleagues, developing relationships and uniting the team.

\section{Conclusions}

Following the interviews carried out, we reached the conclusion that persons of female gender interviewed have more responsibilities within the job as compared to persons of male gender; they also have more responsibilities both at a personalprivate level and a professional level.

There is a tight connection between the professional and personal fields, the problem of employees related to the two fields generates stress, thus negative consequences occur that contribute to a large extent to a change in the state of wellbeing. The solution would be the detachment from the existing problems when passing from one environment to the other.

Commonly, stressful situations generate a state of agitation; from the research it is found that the persons of male gender find solutions more quickly than those of female gender when it comes to fighting stress.

Stress in the workplace is generated by unforeseen factors for which some employees have no control, when it is not within the power of an employee to solve a problem, stress occurs.

From the research, there was found that extroverts find more easily methods of fighting organisational stress. The work team has an important role, that can contribute by the way of being of employees and their cohesion to fighting stress. Communication is important within a team as well.

Most ways of reducing the level of stress in the workplace and fighting it imply directly the employee and less the characteristics of work tasks or elements that regard colleagues. A way of fighting stress in an organisation is represented by the intervention of the department for safety and health at work.

The stress issue is more and more acute today, but with an optimistic view on life and various methods of fighting such as: sport, meditation, friends, hobbies, this problem can be overcome successfully. 


\section{References}

Andreescu, A., Liţă, S. (coord.) (2006), Managementul stresului profesional. Ghid pentru personalul din domeniul ordinii şi siguranţei publice [Occupational stress management. Guide for public order and safety personnel] Bucureşti: Ministerul Administraţiei şi Internelor.

Batâr, D.C. (coord.)(2001). Perspective actuale în psihologie şi sociologie [Current Perspectives in Psychology and Sociology]. Sibiu: Lucian Blaga University.

Bărăian, M., Bărăian, C., Arghir, G. (2010). Climatul comunicarii manageriale [The Climate of Managerial Communication], article published in the Multidisciplinary National Conference, Sebeş, link accesed on 16.02.2019, hour 15:05, available at http://stiintasiinginerie.ro/wp-content/uploads/2014/01/14-CLIMATULCOMUNIC\%C4\%82RIIMANAGERIALE.pdf?fbclid=IwAR2inO_uDufZ7xvrcEAYzPdSeo6 x8Du_0DWm76pBb949zSi5BRWazA9_nsg.

Bogathy, Z. (coord.) (2004). Manual de psihologia muncii şi organizaţională [Manual of Work and Organizational Psychology]. laşi: Polirom.

Emmett, R., (2009). Managementul timpului tău, ghid de gestionare a stresului pentru cei copleșiți de probleme și responsabilități [Your Time Management, A Stress Management Guide for Those Overwhelmed with Problems and Responsabilities]. Bucureşti: Business Tech International.

Fengler, J. (2016). Burnout. Strategii pentru prevenirea epuizării profesionale [Burnout. Strategies to Prevent Professional Exhaustion]. Bucureşti: Trei.

Floru, R., (1974). Stresul psihic [Mental Stress]. Bucureşti: Enciclopedică Română;

lamandescu, I. B. (1993). Stresul psihic și bolile interne [Mental Stress and Internall Illnesses]. București: All.

Necşoi, D.V. (2011). Predictori ai stresului occupaţional în mediul academic [Predictors of Occupational Stress in Academic Environment]. Braşov: Universităţii Transilvania.

Pastor, I., Cîmpean, E.A., Stoica, M. (2005), Managementul firmei şi dezvoltarea resurselor umane în organizaţie [Company Management and Human Resource Development in the Organizations]. Cluj-Napoca: Risoprint.

Preda, V., R. (2004). Efecte ale stresului și strategii de coping la cadre didactice și la elevi [Effects of stress and coping strategies on teachers and students], doctoral thesis summary, Babeș - Bolyai University, Faculty of Psychology and Educational Sciences, link accessed on 19.02.2019, hour 16:50, available at https://doctorat.ubbcluj.ro/sustinerea_publica/rezumate/2010/stiinte\%20ale\%20e ducatiei/Preda_Vasile_Radu_ro.pdf

Selye, H. (1984). Ştiinţă şi viaţă [Science and Life], Bucureşti: Editura Politică.

Simion, M. (2015). Dimensiunea instituţională şi socială a stresului profesional în gestionarea resurselor umane din Ministerul Afacerilor Interne [The Institutional and Social Dimension of Professional Stress in Human Resources Management in the Ministry of Internal Affairs], doctoral thesis summary, Bucharest, Police Academy "Alexandru Ioan Cuza", link accesed on 12.02.2019 hour 15:19, available 
at: https://www.juridice.ro/wp-content/uploads/2015/09/rezumat_teza_simion .pdf.

Stoica, M. (2007). Stres, personalitate şi performanţă în eficienţa managerială [Stress, Personality and Performance in Managerial Efficiency]. Cluj-Napoca: Risoprint.

Stora, J.B. (1999). Stresul [Stress]. Bucureşti: Meridiane.

Zlate, M. (2007). Tratat de psihologie organizaţional-managerială [Manual of Organizational-Managerial Psychology]. Iaşi: Polirom.

Zorleţan, T., Burduş, E., Căprărescu, G. (1996). Managementul organizaţiei [Organization Management]. Bucureşti: Holding Reporter. 